DOI: 10.12775/MBS.2014.003

Medical and Biological Sciences, 2014, 28/1, 17-21

\title{
ULTRAVIOLET RADIATION (UV) INDUCES F-ACTIN REARRANGEMENT AND CELL DEATH IN THE A549 HUMAN LUNG CANCER CELL LINE
}

\author{
PROMIENIOWANIE ULTRAFIOLETOWE (UV) INDUKUJE REARANŻACJĘ F-AKTYNY \\ ORAZ ŚMIERĆ KOMÓREK LINII RAKA PŁUC A549
} Department of Histology and Embryology, Nicolaus Copernicus University in Toruń, Collegium Medicum in Bydgoszcz,
Head: Prof. Alina Grzanka

The human lung cancer cell line, A549, was employed to investigate the effect of UV radiation on the actin cytoskeleton organization in relation to its potential involvement in cell death processes. The light and electron microscopy analysis was performed to find the morphological signs of cell death in UV-treated A549 cells. In turn, the F-actin architecture was determined using fluorescence microscopy after phalloidin-Alexa Fluor 488 staining. We observed apoptosis as well as mitotic catastrophe-like morphological changes in A549 cells exposed to UV radiation. We also found the vacuoles in the cytoplasm of UV-exposed A549 cells, which are considered to be indicative of autophagy. All morphological effects of UV radiation were time-dependent.
Furthermore, alterations in cell morphology corresponded with actin cytoskeleton reorganization. F-actin was presented in the form of dense ring-like structures surrounding the nuclei of cells with apoptotic-like phenotype. Moreover, in some of these cells depolymerization of F-actin occurred. On the other hand, the enlarged cells exhibited strongly expanded actin network. Our study revealed that ultraviolet radiation induced F-actin reorganization, which was accompanied by the characteristic apoptotic features. These results also suggest that UV induces not only the apoptosis but also the non-apoptotic cell deaths and in each of these processes reorganization of actin cytoskeleton is essential.

Streszczenie

W niniejszej pracy użyto linii komórkowej ludzkiego raka płuca, A549, w celu określenia wpływu promieniowania UV na organizację cytoszkieletu aktynowego w powiązaniu z jego potencjalnym udziałem w śmierci komórki. Wykonano analizy na poziomie mikroskopu świetlnego i elektronowego, które umożliwiły określenie zmian morfologicznych wskazujących na indukcję różnych rodzajów śmierci komórkowej pod wpływem promieniowania UV. Filamenty aktynowe wyznakowane zostały falloidyną skoniugowaną z fluorochromem Alexa Fluor 488. Po ekspozycji komórek na działanie promieniowania UV obserwowano liczne komórki morfologicznie podobne do apoptotycznych, jak również te, o cechach morfologicznych charakterystycznych dla katastrofy mitotycznej. W komórkach linii A549 traktowanych promieniowaniem UV zaobserwowano również liczne wakuole cytoplazmatyczne, które są uważane za wyznacznik autofagicznej śmierci komórek. Wszystkie zaobserwowane zmiany były zależne od czasu ekspozycji i korelowały z reorganizacją cytoszkieletu aktynowego. W komórkach apoptotycznych F-aktyna występowała w postaci pierścieni otaczających jądra komórkowe. Ponadto, w niektórych komórkach o fenotypie apoptozy F-aktyna uległa depolimeryzacji. Z drugiej strony komórki powiększone wykazywały znaczne rozbudowanie sieci filamentów aktynowych. Prezentowane badania wskazują na reorganizację cytoszkieletu aktynowego po ekspozycji komórek na promieniowanie UV, która wiąże się głównie z procesem apoptozy. Jednakże, wyniki doświadczeń sugerują, że promieniowanie UV indukuje także nieapoptotyczne rodzaje śmierci komórek, w przebiegu których reorganizacja F-aktyny jest również istotna. 
Key words: sport of people with disabilities, a medical college, a physical education college, male students, female students, profession, views.

Slowa kluczowe: sport niepełnosprawnych, uczelnia medyczna, uczelnia wychowania fizycznego, studenci, studentki, zawód, poglądy.

\section{INTRODUCTION:}

It is well established that ultraviolet radiation (UV), the most prominent physical carcinogen in our natural environment, has adverse health effects on our skin, eyes and immune system [1]. However, the UV radiation has also a few beneficial health effects, which contributed to the therapeutic use of it. Ultraviolet phototherapy is the treatment modality of choice for a large variety of inflammatory and chronic skin diseases, such as vitiligo, psoriasis, parapsoriasis, cutaneous T-cell lymphomas and chronic eczemas [2]. It has also been proposed that UV exposure can suppress the clinical symptoms of multiple sclerosis and reduce blood pressure, improving cardiovascular health. Likewise, there are also several reports suggesting antitumor and antimicrobial effects of UV phototherapy $[2,3,4,5]$. The therapeutic effectiveness of UV phototherapy may be associated mainly with its antiproliferative and immunosuppressive properties as well as the induction of vitamin D and nitric oxide (NO) [2]. Even though UV phototherapy is a standard treatment for various diseases, the mechanisms underlying the cellular UV responses have not been completely elucidated.

As results from literature reports, DNA is considered the major molecular cellular target for the deleterious effects of UV radiation [6]. In addition, the plasma membrane, mitochondria, endoplasmic reticulum, Golgi-complex, lysosomes, and cytoskeleton have also been shown to be affected by UV radiation [6,7]. Furthermore, UV-induced cellular damage triggers apoptosis in a variety of cell types [8,9]. Some researchers have also suggested that rearrangement and/or disruption of actin cytoskeleton are invovled in the process of apoptosis initiated by UV radiation [10,11]. Nevertheless, the effect of UV radiation on cytoskeleton has not been precisely characterized and needs further investigations [11]. Hence, in this study we aimed to assess the actin cytoskeleton rearrangement during the cell death process induced by UV radiation in the A549 human lung cancer cell line.

\section{MATERIAL AND METHODS:}

\section{Cell culture and treatment}

The human lung cancer cell line A549 was purchased from American Type Culture Collection (ATCC, Manassas, $\mathrm{VA}$; CCL-185). The cells were cultured at $37^{\circ} \mathrm{C}$ in a humidified 5\% CO2 atmosphere in Dulbecco's Modified Eagle's Medium (DMEM, Lonza) supplemented with 10\% fetal bovine serum (FBS, PAA) and gentamycin (Sigma-Aldrich). After $24 \mathrm{~h}$ of the culture, the cells were exposed to UV rays for 5 and 15 minutes. Control cells were not irradiated. Cell viability was assessed by the trypan blue dye exclusion method. Briefly, the cells grown on culture flask were harvested by trypsinization with $0.25 \%$ trypsin (PAA) and washed twice with PBS. The cell pellet was then resuspended with $30 \mu \mathrm{PBS}$. $10 \mu \mathrm{l}$ of cell suspension was added to an equal volume of diluted Trypan Blue stain (Sigma-Aldrich). The number of stained cells and total number of cells was counted using Bürker counting chamber.

\section{Light microscopy}

For the morphological analysis, the A549 were fixed in 4\% paraformaldehyde and then incubated with $0.1 \mathrm{M}$ glycine solution. The cells were stained with Mayer's hematoxylin, rinsed under running tap water and dehydrated in a graded series of alcohols and xylenes. The preparations were observed using an Eclipse E800 microscope (Nikon) with NIS-Elements image analysis system and CCD camera (DS-5Mc-U1; Nikon).

\section{Transmission electron microscopy}

For the ultrastructural analysis, the A549 cells were fixed with $3.6 \%$ glutaraldehyde, postfixed with $1 \%$ osmium tetroxide, dehydrated with an ascending series of alcohols and acetones, and embedded in Epon 812. The polymerization of the resin occurred at $37^{\circ} \mathrm{C}$ for $24 \mathrm{~h}$, and then at $65^{\circ} \mathrm{C}$ for $120 \mathrm{~h}$. Selected parts of material were cut into ultra-thin sections by using a Reichert OmU3 ultramicrotome and then counterstained with uranyl acetate. The material was examined using JEM 100 CX electron microscope (JEOL).

\section{Fluorescence microscopy}

Phalloidin conjugated to Alexa Fluor 488 was used to visualize actin filaments (Invitrogen, diluted 1:40). Before labeling, the A549 cells were fixed with $4 \%$ paraformaldehyde, embedded in $0.1 \mathrm{M}$ glycine solution and thereafter permeabilized with $0.1 \%$ Triton X-100. The nuclei of the cells were labeled with 4',6-diamidino-2-phenyloindole (DAPI; Sigma-Aldrich, St. Louis, Missouri, USA). The slides were analyzed by using an Eclipse E800 microscope with a Y-FL fluorescence attachment (Nikon), NIS-Elements 3.30 image analysis system and CCD camera (DS-5Mc-U1; Nikon).

\section{Statistical analysis}

The non-parametric Mann-Whitney U test was performed to compare the differences between untreated and treated cells. The results were considered statistically significant at $\mathrm{p}<0.05$. The GraphPad Prism 5.0 (GraphPad Software) was used for statistical analyses.

\section{RESULTS:}

Viability of A549 cells after UV treatment

The trypan blue assays revealed minimal differences in the median viability of A549 cells exposed to UV rays. Exposure for 15 minutes or less did not result in a statistically significant loss of cell viability when compared to untreated cells. As shown in Figure 1, the median viability rate was $95.9 \%$ in control cells, $94.3 \%$ after 5 min exposure of UV and $93.6 \%$ following 15 minutes of UV treatment. 


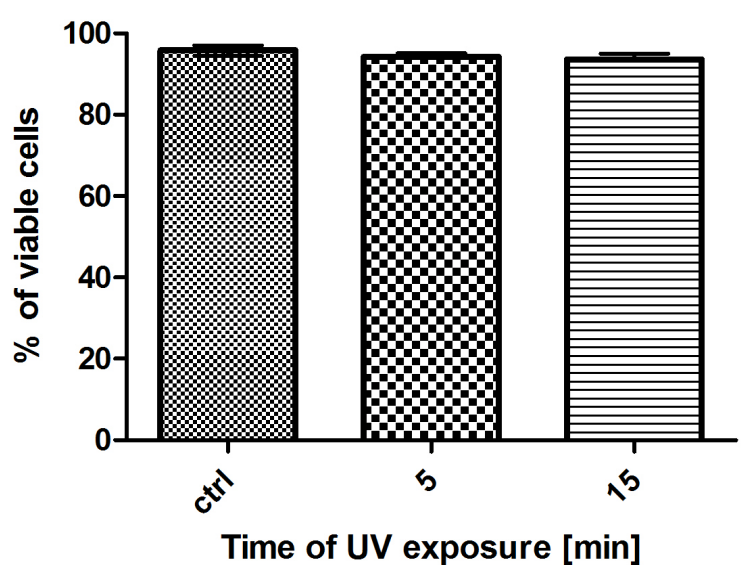

Fig 1. The influence of UV radiation on the percentage of surviving A549 cells. Data are presented as medians and interquartile ranges. Mann-Whitney $U$ test was used for statistical analysis. No statistically significant differences were found between control and UV-exposed cells.

Fig 1. Wptyw promieniowania UV na procent przeżywajacych komórek linii A549. Dane przedstawiono jako mediany $z$ rozstepem międzykwartylowym. Do analizy statystycznej wykorzystano test U Manna-Whitney'a. Nie stwierdzono istotnych statystycznie różnic pomiędzy kontrola a komórkami traktowanymi promieniowaniem UV.

The effect of UV radiation on the morphology and ultrastructure of A549 cells

Control A549 cells exhibited typical short spindle-shaped and triangle-shaped morphology and maintained their adherence to each other (Fig. 2A). Their nuclei vary in shape from kidneyshape to oval (Fig. 2A, 3A). Following UV exposure of A549 cells, dose-dependent morphological and ultrastructural changes were observed. In addition, most of UV-irradiated cells lost their intercellular contacts (Fig. 2B,D). Many of the treated cells became detached and finally rounded up. The rounded up cells exhibited cytoplasmic shrinkage as well as other characteristic signs of apoptosis, including membrane blebbing and chromatin condensation (Fig. 2B,C,D, 3D). Furthermore, at the electron microscopic level, dilatation of endoplasmic reticulum and vacuolization of cytoplasm were also noticed (fig. 3B). A distinct morphology of A549 cells exposed to UV rays was the formation of flattened giant cells with multiple nuclei of different sizes or one big nucleus (Fig. $2 \mathrm{~B}, \mathrm{C})$. This phenotype is consistent with mitotic catastrophe, as described earlier [13].

Fig. 2. The effect of UV radiation on morphology of A549 cells, stained with Mayer's hematoxylin; Control cells (A); The cells exposed to UV for: $5 \mathrm{~min}(B), 15 \mathrm{~min}(C, D)$; The giant cells with fragmented nuclei are seen (B,C arrows I); The giant cell with one big nucleus can be also observed (C arrow II); There are shrunken cells with apoptotic bodies formation (C,D arrows III).

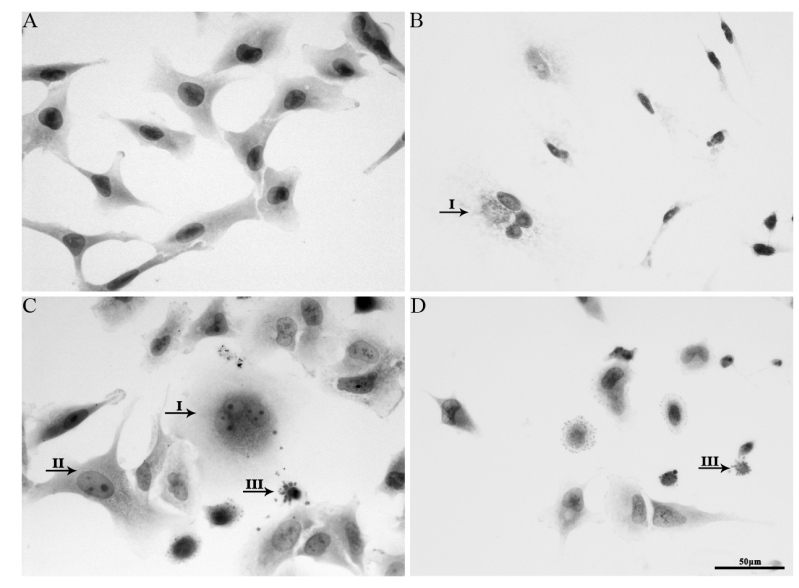

Fig. 2. Wpływ promieniowania UV na morfologię komórek linii A549, barwionych hematoksylina Mayera; Komórki kontrolne (A); Komórki poddane ekspozycji na promieniowanie UV przez 5 min (B) oraz 15 min (C,D); Widoczne powiększone komórki z fragmentacja jądra (B,C strzałki I) lub z jednym dużym jądrem (C strzałka II); Widoczne również obkurczone komórki z ciałkami apoptotycznymi (C,D strzałki III).

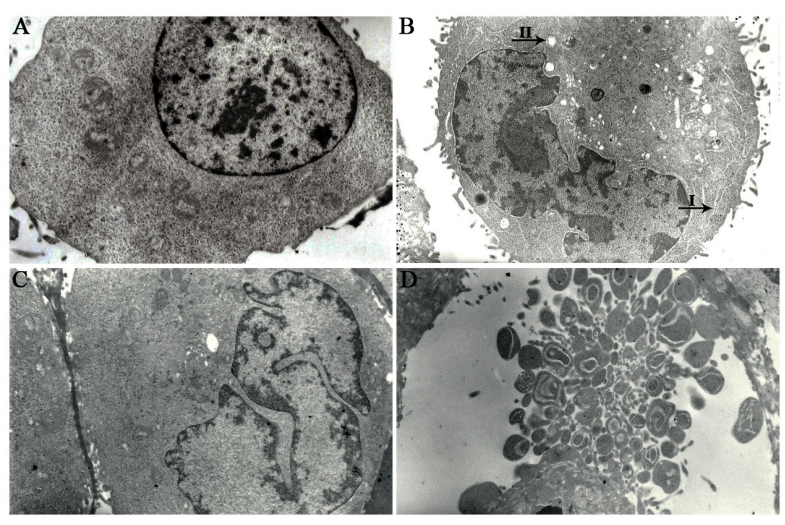

Fig. 3 The effect of UV radiation on the ultrastructure of $A 549$ cells; control cells $(A)$, magnification $\times 5000$; the cells exposed to UV for: $5 \mathrm{~min}(B)$, magnification $\times 5000,15 \mathrm{~min}(C, D)$, magnification $\times 5000$; Dilatation of endoplasmic reticulum (B arrow I) and vacuolization of cytoplasm (B arrow II) can be observed; disintegration of the cell into apoptotic bodies is seen (D).

Fig. 3. Wptyw promieniowania UV na ultrastrukture komórek A549; Komórki kontrolne (A), powiększenie $\times 5000$; Komórki poddane ekspozycji na promieniowanie UV przez $5 \mathrm{~min}(B)$, powiększenie $\times 5000$ oraz 15 min $(C, D)$, powiększenie $\times 5000$; Widoczne poszerzenie kanatów siateczki endoplazmatycznej (B strzałka I) oraz wakuolizacja cytoplazmy (B strzałka II); Widoczny również rozpad komórki na ciałka apoptotyczne (D).

The effect of UV radiation on F-actin rearrangement in the A549 cells

Alterations in cell morphology corresponded with actin cytoskeleton reorganization. In A549 control cells, F-actin 
was predominantly organized in cortical bundles and stress fibers which traversed the cells (Fig. 4A). 5 and 15 minutes of $\mathrm{UV}$ exposure resulted in redistribution of $\mathrm{F}$-actin with partial loss of stress fibers and cell-cell adhesions (Fig. 4B). Actin filaments thick bundles and dots were scattered throughout the cytoplasm (Fig. 4B,C). Other patterns of F-actin rearrangement were found in round and shrunken cells. F-actin in the form of dense ring-like structures surrounding the nuclei was seen in most of shrunken cells (Fig. 4B'). However, in some of them depolymerization of F-actin occurred (Fig. 4C, C'). In addition, a part of the shrunken cells possessed fragmented nuclei (Fig. 4C'). Moreover, the enlarged cells with strongly expanded actin network were also noted (Fig. 4C',D'). The severity of all these changes increased with increase in exposure time.

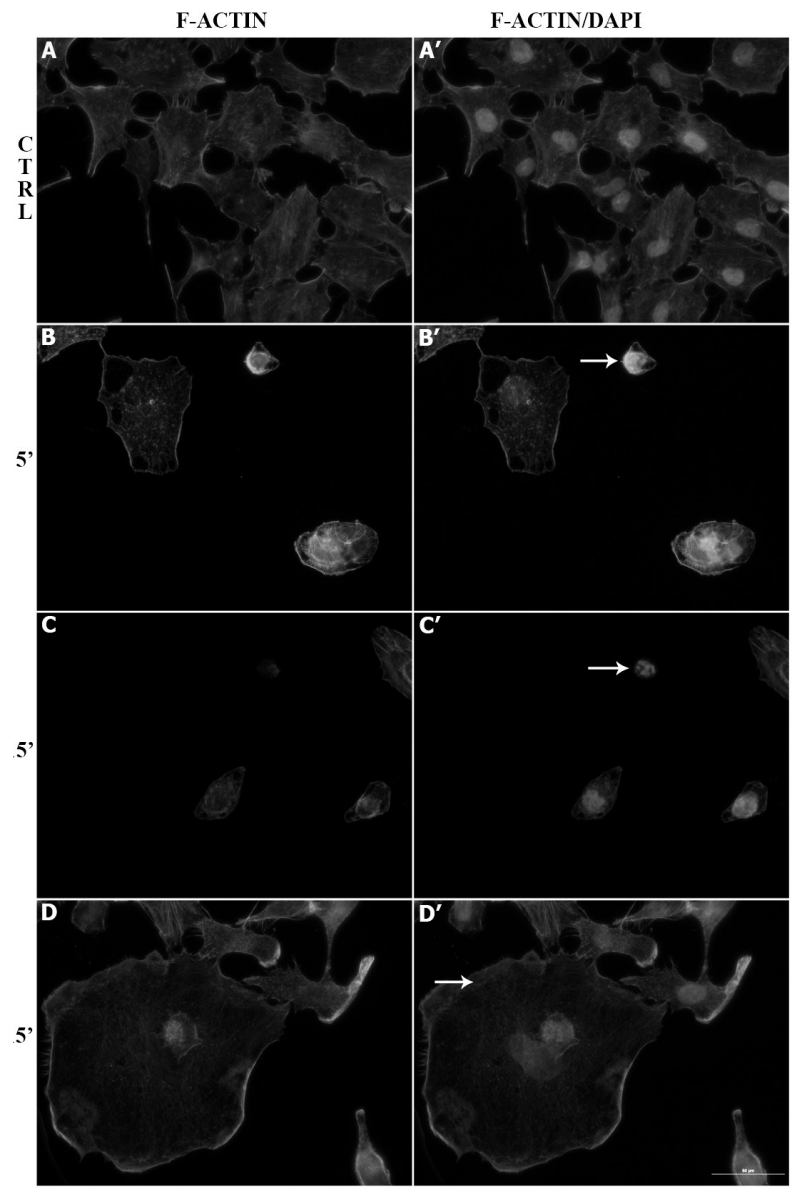

Fig. 4. The effect of UV radiation on the F-actin organization in the A549 cells; F-actin was stained with Alexa Fluor 488 phalloidin, nuclei were counterstained with DAPI; In shrunken cell, F-actin in the form of dense ring-like structure surrounding the nucleus is seen ( $B^{\prime}$ arrow); In shrunken cell with fragmented nucleus depolymerization of F-actin is observed (C'arrow). There is the multinucleated giant cell with strongly expanded actin network ( $D$ 'arrow).

Fig. 4. Wptyw promieniowania UV na organizacje F-aktyny w komórkach linii A549; F-aktyne wyznakowano falloidyna skoniugowana z Alexa Fluor 488, jadra wybarwiono DAPI; $W$ obkurczonej komórce F-aktyna widoczna jest w postaci pierścienia otaczającego jądro komórkowe ( $B$ 'strzatka); $W$ obkurczonej komórce, wykazującej fragmentacje jadra widoczna jest depolimeryzacja F-aktyny (C' strzatka); Widoczne również powiększone komórki z silna rozbudowa sieci F-aktyny (D'strzatka).

\section{DISCUSSION:}

Since its derivation at the beginning of the 70 s of the last century, the human lung cancer cell line A549 has been widely used as an in vitro model in cancer research. Here, we used A549 cells to study the effect of UV radiation on cell morphology as well as F-actin organization and distribution. The light and electron microscopy analysis was performed to find the morphological signs of cell death in UV-treated A549 cells. Apoptosis, the most extensively studied type of cell death, appears to be an important cellular response to UV radiation in various cancer cell lines $[9,10,11]$. We found that the A549 cells exposed to UV radiation exhibited several features of apoptosis, like cell shrinkage, nuclear fragmentation, membrane blebbing and apoptotic bodies formation. The appearance of UV-induced morphological characteristics of apoptosis was also observed by Rehemtulla et al. in the MCF-7 and BJAB cancer cell lines [9]. Furthermore, a distinct morphology of A549 cells exposed to UV rays was the formation of giant cells with fragmented nuclei or one big nucleus. Similar phenotype was described by others in many cell lines treated with various anticancer agents $[12,13]$. The mode of cell death accompanied by the formation of enlarged cells with multiple nuclei of different sizes or one big nucleus is named mitotic catastrophe and it occurs during mitosis as a result of cellular damage as well as the combination of deficient cell-cycle checkpoints [13]. These results suggest that UV-irradiated cells can also die by non-apoptotic mechanisms such as mitotic catastrophe. In addition, we observed the vacuoles in the cytoplasm of UVexposed A549 cells, which are considered to be indicative of autophagy. This observation is consistent with that presented by Grzanka et al., who revealed numerous vacuoles in the $\mathrm{CHO}$ AA8 cells treated with UV radiation [11]. Likewise, Chen et al. demonstrated that autophagy was induced in response to UV radiation of A549 and H1299 human lung cancer cell lines. The cited authors have also pointed out that autophagy acts as a cytoprotective mechanism against UV-activated apoptosis in these cells [14]. Growing lines of evidence indicate the importance of autophagy in cancer. However, it is still unclear if autophagy kills cancer cells or protects them against anticancer treatments [15]. Autophagic cell death, designated type II programmed cell death was first described by Schweichel et al. [16]. Since then, numerous studies have reported that autophagy induced by anticancer therapies may act as an apoptosis-alternative pathway to induce cell death, or act together with apoptosis as a combined mechanism for cell death [17]. Although, in this paper we observed cytoplasmic vacuolization of A549 cells treated with UV radiation, to confirm the incidence of autophagy in these cells, more specific methods for detecting autophagy, such as measurement of LC3II level (an autophagosome marker), should be performed. Nevertheless, the data presented here, allow us to assume that UV radiation promotes apoptosis, mitotic catastrophe and autophagy in the human lung cancer A549 cell line. However, to explain what the role of UV-mediated autophagy in cancer cells is (protective or detrimental), further investigations using additional methods are required.

The second purpose of our study was to determine the influence of UV radiation on F-actin organization and distribution in the A549 cells. We showed that UVinduced morphological changes were associated with actin cytoskeleton reorganization and characterized, at least in part by the disruption of actin stress fibres and cell-cell adhesions. Several other studies also revealed that UV radiation induced the actin cytoskeleton reorganization leading to the destruction 
of cell adherence and consequently to cell death $[10,18,19]$. In addition, we noticed that $\mathrm{F}$-actin was presented in the form of dense ring-like structures surrounding the nuclei of cells with apoptotic-like phenotype. Moreover, in some of these cells depolymerization of F-actin occurred. The rearrangement of F-actin accompaning apoptosis was well documented in many cell lines treated with various anticancer therapies. Besides, it has been documented that depolymerization or cleavage of microfilament networks is also required for major morphological changes associated with apoptosis [20]. Our previous study showed that the reorganization of F-actin was necessary to the realization of apoptosis. In 2003, Grzanka et al. described the presence of F-actin in the apoptotic bodies. That indicates the role of the actin cytoskeleton in membrane blebbing and the formation of apoptotic bodies [21]. The same authors noticed an increase of actin labeling in the nucleus area during apoptosis, and hypothesized that the function of nuclear F-actin may be involved in chromatin remodeling [22]. Here, apart from shrunken cells, we also found the enlarged cells with strongly expanded actin network. Similar results were observed by Nowak et al. as well as Grzanka et al. in the A549 cells treated with cotinine and CHO AA8 cells exposed to doxorubicin, respectively $[23,24]$.

In conclusion, our study showed that ultraviolet radiation induced F-actin reorganization, which was accompanied by the characteristic apoptotic features. These results also suggest that UV induces not only the apoptosis but also the non-apoptotic cell deaths and in each of these processes reorganization of actin cytoskeleton is essential.

\section{REFERENCES:}

1. Armstrong B.K., Kricker A.: The epidemiology of UV induced skin cancer. J. Photochem. Photobiol., 2001; 63: 8-18

2. Juzeniene A., Moan J.: Beneficial effects of UV radiation other than via vitamin $\mathrm{D}$ production. DermatoEndocrinology, 2012; 4: 109-117

3. Opländer C., Volkmar C.M., Paunel-Görgülü A., et al.: Whole body UVA irradiation lowers systemic blood pressure by release of nitric oxide from intracutaneous photolabile nitric oxide derivates. Circ. Res., 2009; 105: 1031-1040

4. Suschek C.V., Opländer C., van Faassen E.E.: Nonenzymatic NO production in human skin: effect of UVA on cutaneous NO stores. Nitric Oxide, 2010; 22: 120-135

5. Morcos E., Carlsson S., Weitzberg E., Wiklund N.P., Lundberg J.O.: Inhibition of cancer cell replication by inorganic nitrite. Nutr. Cancer, 2010; 62: 501-504

6. Schwarz T.: UV light affects cell membrane and cytoplasmic targets. J. Photochem. Photobiology B: Biology, 1998; 44: 91-96

7. Somosy Z.: Radiation response of cell organelles. Micron, 2000; 31: 165-181

8. Schwarz A., Bhardwaj R., Aragane Y.: Ultraviolet-B-induced apoptosis of keratinocytes: evidence for partial involvement of tumor necrosis factor-alpha in the formation of sunburn cells. J Invest Dermatol. 1995; 104: 922-927

9. Rehemtulla A., Hamilton Ch.A., Chinnaiyan A.M., Dixit V.M.: Ultraviolet Radiation-induced apoptosis is mediated by activation of CD-95 (Fas/APO-1), 1997; J. Biol. Chem., 1997; 41: 25783-25786

10. Kulms D., DuĖûmann H., Pöppelmann B., Ständer S., Schwarz, Schwarz T.: Apoptosis induced by disruption of the actin cytoskeleton is mediated via activation of CD95 (Fas/APO-1). Cell Death and Differentiation, 2002; 9: 598608
11. Grzanka D., Domaniewski J., Grzanka A., Żuryń A.: Ultraviolet radiation (UV) induces reorganization of actin cytoskeleton in CHOAA8 cells. Neoplsma, 2006; 53: 328332

12. Roninson I.B., Broude E.V., Chang B.D.: If not apoptosis, then what? Treatment-induced senescence and mitotic catastrophe in tumor cells. Drug Resist. Update 2001; 4: 303-313

13. Castedo M., Perfettini J.L., Roumier T., Andreau K., Medema R., Kroemer G.: Cell death by mitotic catastrophe: a molecular definition. Oncogene, 2004; 23: 2825-2837

14. Chen L-H., Chu P.M., Lee Y.J., et al.: Targeting Protective Autophagy Exacerbates UV-Triggered Apoptotic Cell Death. Int. J. Mol. Sci., 2012; 13: 1209-1224

15. Kondo Y., Kanzawa T., Sawaya R., et al.: The role of autophagy in cancer development and response to therapy. Nat. Rev. Cancer, 2005; 5: 726-734

16. Schweichel J.U., Merkel H.J.: The morphology of various types of cell death in prenatal tissue. Teratology, 1973; 7: 253-266

17. Maiuri M.C., Zalckvar E., Kimchi A., et al.: Self-eating and self-killing: crosstalk between autophagy and apoptosis. Nat. Rev. Mol. Cell Biol., 2007; 8: 741-752

18. Veselska R., Janisch R.: The effect of UV irradiation on changes in cytoskeleton and viability of mouse fibroblasts 1929 cell line. Scripta Medica, 2000; 73(6): 393-408

19. Weinreb O., Dovrat A., Dunia I., et al.: UV-A-related alterations of young and adult lens water-insoluble alphacrystallin, plasma membranous and cytoskeletal proteins. Eur. J. Biochem., 2001; 268: 536-543

20. Desouza M., Gunning P.W., Stehn J.R.: The actin cytoskeleton as a sensor and mediator of apoptosis. BioArchitecture, 2012; 2: 75-87

21. Grzanka A., Grzanka D., Orlikowska M.: Cytoskeletal reorganization during process of apoptosis induced by cytostatic drugs in K-562 and HL-60 leukemia cell lines. Biochem. Pharmacol., 2003; 66: 1611-1617

22. Grzanka A., Grzanka D., Orlikowska M.: Fluorescence and ultrastructural localization of actin distribution patterns in the nucleus of HL-60 and K-562 cell lines treated with cytostatic drugs. Oncol. Rep., 2004 ;11: 765-770

23. Grzanka D., Grzanka A., Izdebska M., Gackowska L., Stepien A., Marszalek A.: Actin reorganization in $\mathrm{CHO}$ AA8 cells undergoing mitotic catastrophe and apoptosis induced by doxorubicin. Oncol Rep., 2010; 23: 655-663

24. Nowak J.M., Grzanka A., Gagat M., et al.: The influence of cotinine on the non-small-cell lung cancer line A549. Post. Hig. Med. Dosw., 2009; 63: 1-7

\section{Address for correspondence:}

Prof. Alina Grzanka

Nicolaus Copernicus University in Toruń

Collegium Medicum in Bydgoszcz

Department of Histology and Embryology

24 Karłowicza St., 85-092 Bydgoszcz, Poland

tel.: +48525853725 ; fax: +48525853734

e-mail: agrzanka@cm.umk.pl

Received: 14.05.2012

Acceoted for publication: 07.01.2014 